\title{
Historical dynamics of Oji Ezinihitte cultural festival in Igboland, Nigeria
}

\author{
Akachi Odoemene \\ Department of History and International Studies, Federal University Otuoke, Bayelsa State, Nigeria \\ E-mail: akaigolo@yahoo.com
}

(Received 6 January 2020; Accepted 16 May 2020; Published 6 June 2020)

\begin{abstract}
Oji (kola nut) is indispensable in traditional life of the Igbo of Nigeria. It plays an intrinsic role in almost all segments of the people's cultural life. In the Oji Ezinihitte festivity the 'kola tradition' is meaningfully and elaborately celebrated. This article examines the importance of $O j i \underline{i}$ within the context of Ezinihitte socio-cultural heritage, and equally accounts for continuity and change within it. An eclectic framework in data collection was utilized for this research. This involved the use of key-informant interviews, direct observation as well as extant textual sources (both published and un-published), including archival documents, for the purposes of the study. In terms of analysis, the study utilized the qualitative analytical approach. This was employed towards ensuring that the three basic purposes of this study - exploration, description and explanation - are well articulated and attained. The paper provided background for a proper understanding of the 'sacred origin' of the $O j i$ festive celebration. Through a vivid account of the festival's processes and rituals, it achieved a reconstruction of the festivity's origins and evolutionary trajectories and argues the festival as reflecting the people's spirit of fraternity and conviviality. Furthermore, in surveying the festival's dynamism within Ezinihitte society over time, it established that the $O j i$ festival is not only a unifying factor but also lies at the heart of community development efforts in Ezinihitte clan.
\end{abstract}

Keywords: Ojị (kola nut), Ojị Ezinihitte cultural festival, Socio-cultural heritage, Historical dynamics, Igboland, Nigeria. 


\section{Introduction}

Oji Ezinihitte cultural festival is one prominent surviving social ritual in Ezinihitte clan, which has become an annual pillar of tradition, culture and development. While Oji (kola nut) holds a very high cultural and ritualistic value among the Igbo - playing a fundamental part in almost all segments of their life - it is in this festive ritual of

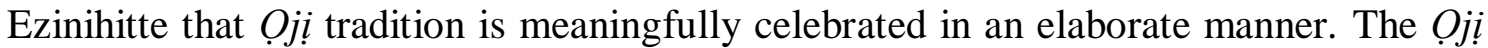
festivity has a history that dates back to the remote past, and hinges on the origins, settlement and culture of Ezinihitte people. The festival generates a sense of community solidarity and, like most other African festivals, is a "great instrument for the dissemination of values so dearly needed to reinforce the philosophy of social harmony and mutual interdependence and the doctrine of community good" (Yalae 2008).

To date, the $O j i$ festivity has remained a symbol of the people's cultural and genealogical unity. It is a medium through which the people of Ezinihitte interact with one another, re-dedicating themselves to the cherished values of Onyeaghalanwanneya ${ }^{1}$ (Odoemene 1997; Ihediwa et al. 2014). However, even as the annual festival is still celebrated - usually as little more than a social function - particularly as a source of joy and gratification over the years, many still lack the appreciation of its original history and significance. Indeed, these have remained 'guesswork' to many, thus susceptible to various opinions and suggestive accounts.

This paper interrogates the origins, historical dynamics (continuity and change), as well as examines the significance of the not-widely-known Oji Ezinihitte cultural festival. To achieve these, this essay is divided into eight sections. The second section, following this introduction, examines the study's methodology, including a survey of the study area. The third section theoretically reviews the place and significance of $O j i$, while the next reconstructs the oral tradition of the festivity, providing its socioreligious backgrounds. The fifth section examines the implications of colonial rule for festivity while the sixth undertakes a survey of the $O j i$ festival in modern times. Diverse perceptions on the festival are interrogated in the seventh section and conclusions are then drawn at the end of the paper.

\footnotetext{
1 'Onye-aghala-nwanne-ya' literarily means "let no one forsake his/her sibling", or in more popular fashion, 'Be your brother's keeper'. Onyeaghalanwanneya is the motto for both the clan and festival.
} 


\section{Research methodology}

An eclectic framework in data collection was utilized for this study. This involved the use of twelve in-person interviews conducted among diverse Ezinihitte indigenes (including male community leaders, women and youth leaders, and a few former traditionalists. In addition, participant observation was employed, which involved the researcher's active participation and observation of the dynamics and processes of $Q j i$ customs and the $Q j i$ festival. Extant textual sources, including archival documents and several other secondary sources - books, journal, newspaper and magazine articles, and few unpublished materials - were equally utilized for the purposes of this study. A constructivist approach in qualitative data analysis was used to scrutinize research findings. The objective was to understand key issues of the study from the perspective of Ezinihitte people. In this respect, meaning was sought from available data, which were patterned for the purposes of critical presentation. This approach allowed the data to speak for itself.

\section{Area of study - Ezinihitte}

Ezinihitte is a clan of the ethnic Igbo. The Igbo homeland is one of the most densely populated in the world (Isichei 1976), and its inhabitants - the Igbo - may have lived in their present locale from the dawn of human history (Isichei 1997). This view supported the Nfunala (autochthonous) claim held by Ezinihitte people, with a history of migration and settlement that indicated their ancestors were kinsmen of the early Ngwa-Igbo stock - a migratory group that arrived and settled in present-day Ezinihitte, while a (second) band migrated further (Dickinson 1931; Isichei 1976; Afigbo 1981; Oriji 1981). Originally made up of eighteen (18) kin-communities ${ }^{2}$ with common ancestry, heritage and culture, Ezinihitte is a local government area (LGA) in Imo State of Nigeria. During the colonial era, three original communities of Ezinihitte - Umuhu, Lagwa and Ibeku (Okwuato group) - were severed from the clan and merged with Agbaja clan (Iheanacho 2012). In the second half of the $20^{\text {th }}$ century a few communities were further merged. These included: Umuchoko and Umueze (Chokoneze), Akpokwu

\footnotetext{
${ }^{2}$ These included: 1. Oboama-na-Umunama (the parent hometowns but always counted as one); 2 . Ife; 3. Umuchoko; 4. Umueze; 5. Ihitte; 6. Akpokwu; 7. Umudim; 8. Amumara; 9. Eziudo; 10. Itu; 11. Okpofe; 12. Eziagbogu; 13. Udo; 14. Obizi; 15. Onicha; 16. Umuhu; 17. Ibeku; and 18. Lagwa.
} 
and Umudim (Akpodim) ${ }^{3}$. Though each community had some degree of 'local autonomy' - distinct market day, separate Aladimma ${ }^{4}$ system, communal feasts, sociopolitical structures and also appropriated and worshiped its own unique deity ${ }^{5}$ - a clanwide worship-ritual in honour of their (Ezinihitte people's) supreme deity, Chileke-Oha (creator-god of all), was jointly held.

\section{The place of $Q_{j i}$ in Igboland: A theoretical review}

Kola nut is a seed which is very popular throughout Nigeria. It is often widely circulated on important social occasions such as marriages, funerals, child-naming or coronation ceremonies, communal meetings, and so on (Opata 1998). Due to its popularity and importance, kola nut has generated a wide range of literature which focuses on diverse perspectives. More importantly, much of the literature has been about its pride of place in Igboland where its customs and rites were very intricate and a complex encounter. These cannot be detailed in any reasonable form in such a work as this. Therefore, an attempt will be made at skirting a theoretical review of the literature on Ojị customs in Igboland, rather than on Ojị Ezinihitte festival - a subject which has received very little scholarly attention. This review takes a thematic approach, focusing on issues which will help one understand better 'the place' of $O j i$-the basis for the cultural festival in focus.

Kola nut tree is of African origin, grown especially in the sultry forests of West and Central Africa (Abaka 2000) as well as in the Caribbean (Nweke 2015). Its fruit comes in pods of which may contain five to twelve seeds, with each seed naturally stratified into two to seven (or more) cotyledons/lobes. It is somewhat enjoyable pleasantly bitter and astringent - much esteemed for its stomachic powers and has an invigorating effect due to its caffeine and stimulating kolanin contents (Hill 1975 cit. Duru 2005). With more than forty varieties, only the cola nitida and the cola acuminata are well known and widely used. The former, popularly called Gworo (Hausa name for kola nut) is the most widely available, while the later is grown mainly in the Igbo hinterlands and is known as $O j i \underline{\text { I }}$ gbo (hereafter known as $Q j i)$ ).

\footnotetext{
${ }^{3}$ These mergers were credited to Reverend David Daniel Africanus Cocker, a Sierra Leonean missionary to Ezinihitte.

${ }^{4}$ Aladimma was a communal socio-juridical system of restorative justice with significant authority.

${ }^{5}$ For instance, there were such smaller deities like Chukwu-Oha (Ife), Alaggbaga (Chokoneze), Aja-ala Amachi (Akpodim), Ifeanimeke (Amumara), Ofo (Itu), to mention but a few.
} 
Kola nut is important in Nigeria, as its three major ethnic groups - the Hausa, Yoruba and Igbo - have some kind of 'interest' in the kola economy which booms in the country, though its symbolic and economic importance amongst them varies almost inversely (Nzekwu 1961). The Yoruba were the largest cultivators of kola nut but have no more than an economic attachment to it. Its consumption was very high amongst the Hausa but, like the Yoruba, no special ritual was involved. The Igbo, however, did not cultivate it, as did the Yoruba, nor consumed it as much as the Hausa and other northerners who basically ate much of it for its diverse roles (Nzekwu 1961). But it was the Igbo that had the strongest emblematic attachment to kola nut (Nzekwu 1961; Duru 2005). Ojị was highly important, widely used and virtually indispensable in their traditional life, thus reverenced and celebrated amongst them (Odoemene 1997).

\section{a) Meanings and symbolic significance}

In pre-colonial times, the day typically began for the freeborn ${ }^{6}$ Igbo man with a visit to his shrine with $O j i$ and $N z u$ (cream-colored edible clay chalk) to thank his $c h i$ (personal god) for keeping him alive (Achebe 1958). Duru (2005) aptly captures the scenario thus:

He prayed to his chi with kola [nut], broke it (noting the number of lobes), threw a lobe to Ani (the earth goddess), threw a piece before his personal shrine, gave a piece to his ancestors, drew symbolic lines with the white chalk ( $i k a n z u)$ in front of his personal shrine, and then ate a piece of the nut. This early Morning Prayer was very important for him, his household (dependents, wives, children, slaves, etc.), and the community.

Furthermore, welcoming guests - whether privately or in public gatherings was usually an important ritual for the Igbo, for whom to be presented with $O j i i$ was to be made welcome (Uchendu 1965). Oji represented goodwill and good fortune, peace, kindness and love, as well as fraternity, integrity and acceptance with a clear, clean

\footnotetext{
${ }^{6}$ Freeborn (Nwadiala or Diala for short) is a 'full citizen' in Igbo society, in contradistinction to the ranks of Ohu (slave) or Osu (outcast/devotees of the gods) who is a 'non-citizen' or 'half-citizen' respectively. 'Freeborn' is a sociologically non-discriminatory rank for full citizens that includes titled and untitled individuals of whatever social or economic class. Cf: Ejiogu (2015).
} 
heart (Odoemene 1997; Anidobe and Uzoalor 2010). It was the height of hospitality and commensality, and ultimately symbolized an act of respect (Anidobe and Uzoalor 2010). It was usually a primary item presented or offered to guests as a show of acceptability, whether or not any other foods or drinks were to be presented. Indeed, $Q j i$ is foundational to all Igbo meetings or gatherings (Offiaeli 2015) as it is the greatest symbol of Igbo hospitality and surpasses any other sign of such (Uchendu 1965; Egbufoama 2008).

If $O j i$ was not presented to a guest by his host, no matter how lavish and sumptuous the entertainment, the guest never felt welcomed (Uchendu 1965; Ihediwa et al. 2014). As Basden (1966) puts it, "[T]he Igbo welcome is not complete without the sharing of the kola nut". Similarly, no ritual or traditional performance was complete without the presence of $O j i$ (Anidobe and Uzoalor 2010). To be sure, any guest who was not offered $O j i \underline{\text { during }}$ any visit assumed and/or voiced out his non-acceptance with a clean heart, unless a clear, often 'diplomatic' explanation was made by the host. Likewise, if a guest rejected $O j i$ offered by a host, it was taken as a sign of bad intent. However, it is only in situations of conflict or mutual suspicion between two parties that the presentation of Oji can be deliberately avoided (Okoloye and Enemuo 2019).

There appears to be a conflict of interpretation about the 'first' item presented to guests. Some scholars argue that $N z u$ was usually the first, after which came $O j i$ (Chukwunyere 2004; Duru 2005; Acholonu 2008), thus emphasizing the prominence of the former over the later. However, this clearly contrasts from widely-held view on the matter. Uchendu (1965) summarizes this view thus: “...[T]he kola nut always comes first. It is the king." This was even as $J i$ (Yam) was the 'king of all crops' (Achebe 1958). For instance, Iri Ji Ohụ (New Yam festival), which honoured Ahiajọu, the Yam deity, cannot commence without $O j i$ rites (Duru 2005). While $O j i$ w was not 'king of crops', it was clearly the 'Master of Ceremonies' (Khoko 1984), without which no occasion really commenced (Odoemene 1997; Opata 1998; Ihediwa et al. 2014). Its indispensability was well articulated in the proverb: Ma Oji abiabeghị, agaghi igbu ehi

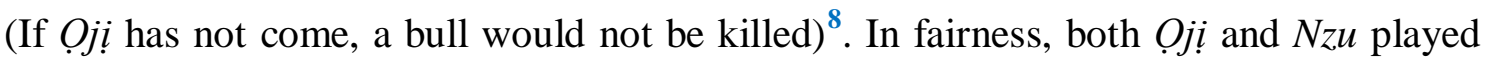

\footnotetext{
${ }^{7}$ Being 'king' in this respect is strictly in terms of hospitality and making guests welcome.

${ }^{8}$ In other words, even as the bull is considered a 'big animal' and any ceremony that requires its slaughter must be equally "big", such ceremony, however, cannot proceed without $O j i \underline{\text { rites }}$ duly performed.
} 
such critical roles ${ }^{9}$, but Ojị's role was not just fundamental and valued, but also indispensable (Nweke 2015), unlike $N z u$.

Being considered 'first' (as noted earlier) meant there was something about $Q j i$ that was alluring - the fact that it unequivocally symbolized (and truly is) Life. This was embedded in a common saying: "Onye wetara Oji wetara ndu" (He who brings kola brings life) (Achebe 1958; Odoemene 1997; Egbufoama 2008; Umeogu et al. 2019), which always re-echoed at the presentation of $O j i$. Both the concept and rites pertaining to $O j i$ s supported the life-affirming Igbo philosophy which was centered on the human person, hence Ndu bu isi ('Life is paramount'/'life is first'). Apart from affirming life, it was also a symbol of continuity of the entire life process as a continuum (Egbufoama

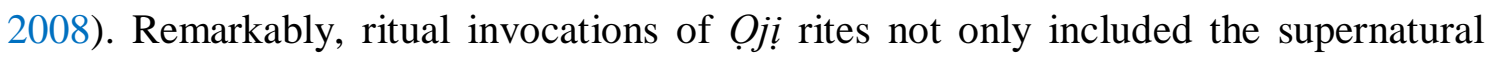
spirit forces - the givers and sustainers of life - but customarily ended with an affirmation of life.

Though a small seed in terms of appearance, $O j i$ was considered 'big' in Igboland. It was a "sacred nut""10 (Achebe 2012; Classycut 2012), which importance was socio-ritualistic (Chidume et al. 2015), encapsulating the essence of 'communion' an act or instance of sharing and commensality. The concept of 'Ojị communion' was climaxed in Iwa $O j i$ (breaking of $O j i$ ) activity which implied the invocation and invitation of the supernatural $\left(C h u k w u,{ }^{11}\right.$ the deities, spirit forces, $c h i{ }^{12}$ and the ancestors) firstly to commune with them, and inhabit the occasion or to bear witness to pending event for which $O j i$ was offered and blessed. The meaning was beyond the saying of the prayers as it follows a ritualized invitation of the supernatural to partake and intervene in the activities of man (Umeogu et al. 2019).

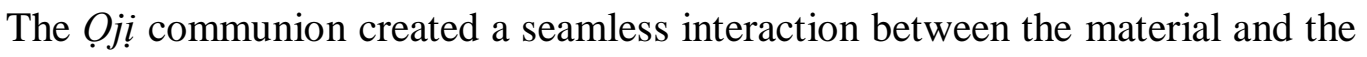
immaterial world - the physical and meta-physical (Umeogu et al. 2019). The supernatural were 'dumb' to what the livings were doing, until the arrival of Oji, without which humans have excluded the gods and ancestors from that ceremony. This 'holy communion' was a cultural practice which transcended the life of the Igbo in its entirety, creating no distinction between the sacred and profane, fact and fiction, natural

\footnotetext{
${ }^{9}$ Instructively, both items played most significant roles in the festival in focus, both in ancient and modern times.

${ }^{10}$ Indeed, as Anidobe and Uzoalor (2010) point out, due to its sacred nature, the dry wood of $O_{j i}$ tree was never used as fuel (fire-wood) in Igboland.

${ }^{11} \mathrm{Chi}-U \mathrm{Kw} w / \mathrm{Chukwu}$ (the big god) is the supreme deity in Igboland. It is also the creator-god of the world (Chineke/Chileke)

${ }^{12} \mathrm{Chi}$, is the personal (small) god which everyone had. It was not the common god of all, often considered 'big' and supreme.
} 
and the supernatural (Obiefuna 1978), as well as uniting the material and immaterial (Umeogu et al. 2019). Thus, to the Igbo, Ojị was always received and consumed in sacred communion. This was the reason why it was at the forefront of Igbo cultural affinity and pervaded every aspect of human existence - social, economic, religious and political.

Despite the diversities and differences in Igbo culture, $Q_{j i}$ tradition is, to a very large extent, somewhat ethnically homogeneous. It has, therefore, much of the same distinctive characteristics throughout Igboland - so much so that has necessitated many to associate the root word, 'Oji!', as an acronym for Omenala Jikotara Igbo ('tradition that unites the Igbo'). This aphorism typically underlines the universality of Oji customs (Umeogu et al. 2019; Okoloye and Enemuo 2019), even as there existed some ambivalence with such across Igboland. This reality epitomizes the unity in diversity of Ojị (Nwosu 2003), especially as an item that both embodies and acts as a unifying force (Nzeako 1979).

Oji Igbo (cola acuminata) comes in two distinct colours - off-white and light pink. Of these, it is the off-white specie - popularly known as Oji Ugo (Eagle kola nut) - that is treasured more. Noting its unique significance, a saying goes thus: Oji Ugo ana-echere nwaeze (Eagle kola nut which is presented to the noble). It is symbolic of royalty and purity and attracts blessings and luck (Egbufoama 2008). One other peculiarity of $O j i$ I Igbo is that it often has several lobes (cotyledons), ranging from three to seven, or occasionally more (Opata 1998; Okoloye and Enemuo 2019). The number of lobes that Oji naturally breaks into have cultural connotations, and thus such is taking into serious cognizance. As Achebe (1958) contends, "many profound and mysterious interpretations and formalities" are accorded to such number of lobes ${ }^{13}$.

\section{b) İ Ojị: Stages in the ritual communion}

I $w a O_{j} !^{14}$ is a very solemn spiritual ritual. It constitutes a piece of 'drama' reflecting the spiritual and social realities of the people, their mores and relationships (Nweke 2015). Chidume et al. (2015) note that the rites of Iwa Ojị symbolized a social and ritual bonding between on the one hand the living, and the departed/supernatural, on the other hand. It is a ceremonial covenant of hosts and guests with benevolent ancestral

\footnotetext{
${ }^{13}$ The author craves the indulgence of readers about the cultural and spiritual connotations of the different numbers of each kola's lobes which this article does not go into, because of its desired/intended size.

${ }^{14} I w a O j j i$ is a generic term used to define the entire $O j i$ ritual and communion, as well as an aspect of the rites in that $O j i$ ritual.
} 
spirits and deities in the presence of Ani (Ala), the earth deity." This process was actually much more solemn and a symbol of hospitality than was often recognized. It is 'a sacred communion' during which the living enters into a covenant-partnership with the departed, for the adulation of the deities (Odoemene 1997). For the livings, the customs were complex and actually depended on or pertained to hierarchies - mainly affinity, age and status - of males or groups present at any given occasion.

Uchendu (1965) postulates that there were three stages involved in Iwa Oji custom: Iche Ojị (the presentation), Iwa Ojị (the breaking) and Ike Ojị (the distribution of the broken pieces). This position is somewhat supported by Nweke (2015) - agrees to a three-stage position, but presents a new stage, distinct from Uchendu's (2015), amongst the three, though contradicting himself later. Nweke's (2015) stages included: Igo Oji (the consecration/blessing), Iwa Ojị (the breaking) and Ike Ojị (the distribution). Both positions are however, thought to be erroneous and misleading. Truly, the discrepancy in these positions provided 'the missing link'. Uchendu (1965) inadvertently missed out the most important of the stages - Igo Oji (the solemn consecration/blessing), just as Nweke (2015) did I che Ojị (the presentation). Certainly, there existed four stages: (1) Iche Oji (the presentation); (2) Igo Ojị (the blessing); (3) Iwa Oji (the breaking); and (4) Ike Oji (the distribution) (Odoemene 1997; Duru 2005; Apakama 2012).

(1) For Iche Oji, Uchendu (1965) clearly notes that it was the host's privilege to present $Q j i$ i to the guests. This presentation - a rather quick activity - was a 'males exclusive affair' for any occasion; it was a form of recognition and acceptance. This was the most common practice, but certainly not pan-Igbo. For instance, in Oguta, Oji was the most important item offered to gods and visitors alike - whether female or male. Offerings to Ala, the earth-goddess, or Ogbuide, goddess of Oguta Lake, would be worthless without $O j i$. Instructively, these deities' female priestesses were the first to whom $O j i$ i was presented ('shown') during any ceremonies involving the deities (JellBahlsen 2014). Their female guests had similar treatment (Ibid).

After presentation, the $O j \underline{j}$ i began its 'relay' - a movement from one male (or kin-group) to another, in order of affinity. This was for acquaintance as the people present found out who came from where (Chidume et al. 2015). Hence, whenever Oji embarked on the relay, it was said that Oji agawala ije ịtu agburu (Oji has embarked on a journey to establish lineages). This activity helped to trace kinship and linked lineages amongst guests. In this process of relationship reaffirmation, no person or group was 
neglected/omitted for whatever reason. Such would be a horrible and shocking slight to 'the victim. By omitting him, his origin, lineage and being a man, were being put to question. Indeed, this was a taboo often completely avoided, even among enemies, or which must be assuaged immediately, if done (Odoemene 1997). Conversely, wrong/faulty relays - passing the $O j i$ to the wrong person - especially in agnate (Umunna) settings, were seriously frowned at (Anidobe and Uzoalor 2010; Chidume et al. 2015) and sometimes penalized (Odoemene 1997).

(2) Igo Oji, essentially a prayer (consecration and blessing) session, was the climax of $Q j i$ communion rites. These prayers were offered to bless the people and consecrate $O j i$ in the presence of higher supernatural beings, as noted earlier. The prayer's tone was that of invocation, dictated by the nature of the occasion. The person who said the prayer and consecrated $Q j i$ - often a titled man in whose absence an untitled person presided, preferably the oldest man present ${ }^{15}$ - was expected to 'speak well' and to bless at all times, or no one may eat the $O_{j j} i^{16}$ (Odoemene I997). During this invocation, he ritualized himself and the whole humanity, poured out his heart with $O j i$ in his hand (Nweke 2015; Umeogu et al. 2019). He used the invocation of Oji to forge a link between the living and the supernatural forces, entreating the later to be witnesses to the ceremony's proceedings (Okoloye and Enemuo 2019).

Structured to capture a kind of superior-inferior hierarchy, the prayer/invocation thanked the gods and benevolent ancestors for their protection, guidance and provisions, as well as summoned the discernment of all good tides and rejection of all evil antecedents. It also blessed all those present and was used in consecrating the $O j i$ with which the people were blessed and the divinities summoned. The invocation came in clauses with each clause specific about an issue, usually in idiomatic expressions. Since the language of the ritual invocation was divine, only supernatural beings were addressed with it (Nweke 2015). The prayers offered often concerned a variety of human needs (Duru 2005), while the expressions were habitually soothing and capable of enriching lonely human souls (Odoemene 1997). Igo Oji activity was a thing of courage intended for the fortification of the divine people present.

The invocations and blessings were rendered exclusively in Igbo language. The

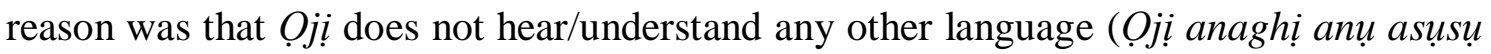

\footnotetext{
${ }^{15}$ It could, however, be a person 'elected' to do so by those present. If there was a mixture of different peoples or groups, it was the oldest man from the host's side that consecrated $O j i$.

${ }^{16}$ No host wished for this, as refusing $O j i$ meant the rejection of friendship with the goodwill and respect it came with.
} 
ozo) - a strongly-held belief among the Igbo. Thus, it must be addressed, consecrated and used to bless the people only in that native language (Odoemene 1997; Egbufoama 2008). However, this art required proficiency in the language, as it involved good oratory which projected its seriousness (Nnamdi-Eruchalu 2012). At its end, the invocation was affirmed by a collective acclaim: Iseeee! (Let it be so), by all.

(3) After the prayers of invocations and blessings, $Q j i$ was broken into smaller bits. This was Iwa Ojil- oftentimes done in accordance with the number of persons present. Instructively, there were remarkable differences in different Igbo societies as to how this aspect of the $O j i$ custom was carried on. In Agukwu-Nri, for instance, before the Eze Nri, (King of Nri) ${ }^{17}$ only a little boy or girl, a representative from Adama (the priest of the king's divinity) or a midget may break Oji into bits (Nzekwu 1961). Elsewhere, any young male was called upon to perform this task; while some other Igbo communities insisted on the youngest male present in the gathering did so (Odoemene 1997). Due to its sacred nature, however, any man who committed an abomination murder, incest, sacrilege, and so on-would not break $O j i$, nor even partook in its consumption until the gods were appeased and such a person cleansed (Anidobe and Uzoalor 2010).

(4) Ike Oji came next. For this activity, the broken bits of the nut were meticulously shared to all persons present, irrespective of gender, age or status. This was often carried out in order of seniority (age/rank), or in the order people were seated, for convenience. Everyone partook in this 'holy communion' and one was never consciously omitted, unless he/she declined the offer on personal volition, but certainly not out of malice (Odoemene 1997). The shared Oji was eaten under a sense of solemnity and reverence (Chidume et al. 2015).

\section{c) Discriminations and exclusions in $Q_{j ! ̣}$ customs}

Despite the lofty ideals and claims about $O j i$ customs and rites, it is clear that there were certain contentions, dissentions and counter interpretations about such beliefs. In this section, such claims would be critically examined. One claim was the 'democratic content' ascribed to Ojị communion (Nnamdi-Eruchalu 2012), while the another has to do with Anidobe and Uzoalor's (2010) assertion of the non-

\footnotetext{
${ }^{17}$ Nri was a prominent medieval polity in Igboland. It is located in the present Anambra state of Nigeria.
} 
discriminatory or exclusionary nature of $O j i$ customs, which also feeds into the earlier claim.

Nnamdi-Eruchalu (2012) had contended that Oji customs were encoded with certain 'democratic contents' which marked it out as unique. This claim is contentious, particularly as there existed certain practices which were clearly undemocratic. One key example was that customarily not everybody could break Oji. For instance, as Odoemene (1997), Anidobe and Uzoalor (2010) and Uchenna (2010) note, the Osu (outcasts) and $O h u$ (slaves) never broke or consecrated $O j i$ at meetings involving the Diala (free born). Evidently, this was undemocratic and clearly excluded a significant population of society on account of social status. This is contrary to the claim, surprisingly, by same Anidobe and Uzoalor (2010) that $O j i$ " "sharing practice is the only Igbo social institution that does not discriminate in terms of class or status".

The position above suggests the absence of discrimination or exclusion in $O j i$ customs. Further instances of gender-based discriminations associated with $O j i \underline{\text { would }}$ suffice. Indeed, most Igbo societies were patriarchal, and sometimes rigidly paternalistic and agnatic. In other words, the principle that woman should be 'seen and not heard' was fully operational. This also presupposes that the society possessed elements that inadvertently 'inferiorized' the female folk. As Uchendu (1965) notes, presenting and partaking in $Q j i$ c communion was "a privilege denied to women and other social inferiors;... woman may not carry out any of these steps." In many communities, women/females were not permitted to take part in the $O j i$ customs in whatever way,

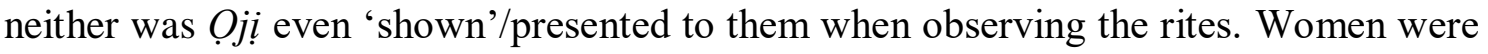
only 'noticed' when the consecrated $O j \underline{j}$ i were shared, bits of which they got (Anidobe and Uzoalor 2010; Chidume et al. 2015; Umeogu et al. 2019).

Even in women's autonomous groups' meetings, any available male was invited to perform Qji rites for such gatherings (Duru 2005; Offiaeli 2015). Again, females were to bow down their heads or semi-kneel when handing $O j i$ bowl to a husband or father to present at occasions (Offiaeli 2015), and such must not be during their menstrual cycle or Ọụgwọ (postpartum period) (Ogbonna 2004; Chidume et al. 2015). Again, it is an abomination for females to climb the $O j i$ tree, pluck/harvest its pods or pick the fallen pods, even if the tree was hers, where she was privileged to own one (Chidume 1998; Anidobe and Uzoalor 2010). Women were also forbidden from planting Oji tree (Okoloye and Enemuo 2019). Another enlightening angle to the endered discrimination was the fact that $O j i$ which had no lobes, commonly known as 
Ojị dara ogbi ('Dumb kola nut') and forbidden and unfit for consumption, can only be eaten by pregnant women (Opata 1998).

To do any of these societal breaches noted above was considered quite abominable and must be confessed to and atoned for through spiritual reparations (Umeogu et al. 2019). Such a practice is also instructive about women's place in the society. Though Okoloye and Enemuo (2019) have argued that such denial of women in Oji customs did not imply inferiority of women, this argument is implausible and clearly contradicted by Uchendu's (1965) position above. Undeniably, such Ojị rules "silence[s] women and limits their cultural socio-civic participation in the public sphere" (Offiaeli 2015). While these were practiced in some Igbo societies or true in

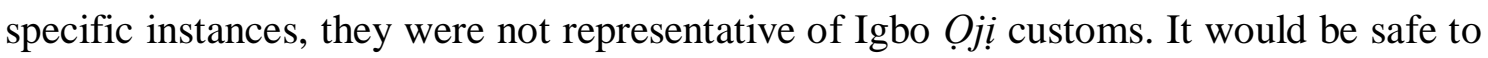
argue that $O j i$ customs have never been an exclusive male preserve, as often presented.

For instance, among Oguta people, women who were past menopause age partook in all Oji rites (Jell-Bahlsen 2014; Ihediwa et al. 2014). Again, in few communities, advanced women who never witnessed menstruation in life, thus considered 'masculinized', also participated in the rites (Odoemene 1997). Again, allusions of discriminations in $O j i$ customs contradicted the core Igbo cultural tenets of gender balance - dualism or binarism. Achebe's idea of "Ife kwụlụ, ife akwụdebe ya" (something stands, something else stands beside it) (Achebe 1958) eminently supports these. Such cultural duality was replicated in Igbo belief systems (Osuagwu 2000; Nnaemeka 2013). Lastly, as have been noted earlier, Oji invocations and blessings were performed strictly in Igbo language. This has implications. Though the indulgence of non-Igbo guests was craved and what transpired explained to them (Chidume et al. 2015), this practice was thought to be discriminatory.

As has been amply demonstrated, $O j i$ was an indispensable element in traditional Igbo life and played intrinsic roles in all facets of their cultural life (Odoemene 1997). Despite the very high value for and universal reverence of $O j i$ throughout Igboland, it was only in Ezinihitte that a festival was properly named after it and dedicated purely for its veneration. Arguably, it was in this Ezinihitte festivity that Oji customs and rites were evocatively, flamboyantly and continually rehashed in the most public, communal and pervasive manner. Indeed, in this festival, the popular view that 'the Igbo celebrate kola nut' was meaningfully exhibited. It truly constituted a socio-cultural system which elaborately ‘eventified’ Igbo Oji rituals. 


\section{Emume Chileke-Oha: an oral tradition narrative}

Upon their arrival and settlement around Orieukwu (Orukwu) in Umunama, the ancestors of Ezinihitte clan instituted for themselves a monotheistic religion based on the worship of Chileke-Oha Orieukwu (creator-god of all of Orieukwu) - a god who created, guided and protected them all through life. Orieukwu is believed to be "the seat of the creation of the world and the spirits" (Dimgba 1997: Interview), and by implication the cradle of mankind (Odoemene 1997). The people worshipped ChilekeOha which not only protected them (and all humans in all their activities) and provided their needs throughout their migration, but also gave them rain, sun and moon, and also made their crops grow (Odoemene 1997; Osuagwu 2000).

There were two main types of religious rituals performed by Ezinihitte people before the shrine of Chileke-Oha in pre-colonial times. The first was when a person, family, kin group, village or community sought blessings for, or wished to prevent evil attacks on some of its members. This did not require the entire clan to be in attendance; rather, those affected went to perform sacrifices and offer prayers at Orieukwu. The second were the clan-wide festivals: Iro Mmuo (delighting of the spirits), Iri Ji Ohuب (the new yam festival), and Emume Chileke-Oha ${ }^{18}$ (feast of Chileke-Oha). These were aspects of their ancient religion. During these feasts, the whole clan approached their supreme deity to worship and pray for general prosperity. Of these worship-rituals, the most significant was Emume Chileke-Oha (Onuoha; Chilaka 1997: Interviews) which was preceded by the other two rituals. It was held once a year on an Orie-Ukwu (big Orie) market day in the seventh traditional month. Emume Chileke-Oha was the singular identity of the common ancestry and genealogical affinity of Ezinihitte people (Chilaka; Izima 1997: Interviews). This worship-ritual "became the pivot of their unity as they congregated" (Ngumah 1984).

Officials who attended the Emume Chileke-Oha included Ndị Ichie (titled elderly men), Ndi Okpa-Ofo (Ofo ${ }^{19}$ holders), Ndi Opara (members of first sons' association) and some eminent Dibịa (diviners). Onye Isi Eze-mmuo (priest) of Chileke-Oha, who

\footnotetext{
${ }^{18}$ The full name of the feast is Emume Chileke-Oha Orieukwu (Feast of Chileke-Oha at Orieukwu).

${ }^{19}$ Ofo is an aspect of Igbo ethos of transparent living and "the symbol of ritual authority" invoked to profess or legitimize one's innocence. Cf. Uchendu 1965.
} 
hailed from Umuoshi village in Umunama ${ }^{20}$, presided over Emume Chileke-Oha worship-ritual. Each community was led by its respective Eze-mmuo (priests) who assisted Onye Isi Eze-mmuo (Izima 1997: Interview). Emume Chileke-Oha was immediately preceded by Izu Udo, an eight-day 'amity week' which started on Orie nta (small Orie) market day. During the week, fighting, quarrelling, enmity were absolutely forbidden $^{21}$. An important event within this 'sacred period' was a mysterious night race, Oso Nwannunu Ogala mmuo Ihu Chileke Orieukwu ${ }^{22}$ (mystic bird's race to the throne of Chileke at Orieukwu), led by the Eze-mmuo of the shrine of Amachi-Akpokwu (Ugo 1993). According to Izima (1997: Interview), Osọ Nwannụu was an all-male spiritual race which was performed naked, and it was aru (a taboo) for 'mere men' to witness the race or behold the racers ${ }^{23}$.

Oso Nwannunu, the significant harbinger of the annual worship of Chileke-Oha - which remains an important mystery - terminated at the shrine of Chileke-Oha where the racers made a symbolic visit to Odi Uhie adighi Okwogho, a gigantic granite rock which is a highly revered hallowed ground. The visit was to pay homage to and rub $\mathrm{Nzu}$ Uwaoma (White-clay of good life), which symbolized peace, purity, wealth, love and unity (Izima 1997: Interview), before the commencement of the festive ritual (Izima; Chilaka 1997: Interviews). Ezinihitte elders called the rock Mputara Uwa, as they believed it existed since the world's creation (Chilaka 1997: Interview). Four days after the bird's race, Ikwa Omu (decoration of the place of worship with palm fronds) was done. $O m u^{24}$ were used to decorate the entire place of worship, and sign the trees, especially the $U h a^{25}$, found in the premises of the shrine. The spot where Onye Isi Ezemmuo placed his well-decorated carved stool was also beautified and 'signed' with $O m \varphi$ (Izima 1997: Interview).

On the festival day proper, the different Eze-mmuo came before Chileke-Oha to draw inspiration and power. Throwing more light on the nature of the worship-ritual proper, Chilaka (1997: Interview) asserted that:

\footnotetext{
${ }^{20}$ His assistant came from Oboama community.

21 This tradition was also noted by Talbot (1926) as a significant feature of the New Yam festivals in several districts of Igboland.

22 Often shortened to Oso Nwannunu (bird's race).

23 The race was widely announced so no one moved around from dusk till dawn. As a safety measure, $N d i$ Di-Mmiri (rain-makers) often invoked heavy downpours of excessive rain on that day to avoid people encountering Oso Nwannunu and, perhaps, losing their lives (Izima 1997: Interview; Ugo 1995).

${ }^{24} \mathrm{Om} \varphi$ is the freshest fronds of the oil-palm tree; it was often associated with spiritualties.

${ }^{25}$ Uha tree was considered a 'sacred tree' in Ezinihitte. It was planted all around the shrine of ChilekeOha of Orieukwu.
} 
Each Eze-mmuo...came down to Orieukwu with people who had problems of diverse nature. These people would bring gifts to this worship-feast which involved praying, dancing and other festivities. The gifts included $Q j i$ - a prominent substance - Mmanyịkwu (palm wine), Mkpi ('He-goat'), cocks and fowls, prepared food and importantly too, $\mathrm{Nzu}$ which was used for a particular blessing. Onye Isi Eze-mmuo, with the other priests, took all the gifts to the shrine and offered prayers and sacrifices to Chileke-Oha. They blessed the items and had them prepared for consumption.

No one ate or drank anything at the feast until the special function of Ithu Aka was performed by Eze-mmuo of Amachi-Akpokwu and his henchmen. Invited to perform this function, he poured libations, and with incantations, recounted the good things in Ezinihitte in the year, which he attributed to the mercy of Chileke-Oha. The Eze-mтмч also mentioned disastrous events and described them as unfortunate. In a solemn manner, he invoked Chileke-Oha for mercy and protection of all. Lastly, he thanked the god for providing food and drinks and sought permission and protection to eat before the shrine. These narrations were solemnized in the spirit of actual worship. He then blessed the whole proceeds of the ritual (Ugo 1995). It is noteworthy that the importance of Ithu Aka led to a popular saying: Ma Akpokwu adighi thuo Aka" (if Akpokwu has not done Ithu Aka, [nothing can proceed]) (Ibid). The Eze-mmuo concluded Ithu Aka by touching his throat and lips, thus signaling the commencement of feasting. With such 'invitation', the worshippers soon regaled themselves on the sacrificial foods (Chilaka; Izima 1997: Interviews).

The end of Ithu Aka signaled the beginning of the Uko music - the official music for the festival. It was danced to by Onye Isi Eze-mmuo, and then by others present. At the end of the dance, all the things used for the sacrifice were shared out 'accordingly' by the Onye Isi Eze-mmuo. According to popular legend, Ife community got Isi-anu (the head) of all the slaughtered and prepared animals ${ }^{26}$. Akpokwu group got all Abah-anu (jaws) of the animals ${ }^{27}$, while all the fore-legs went to Chokoneze and Ihitte. Umunamana-Oboama got the hind-legs, and other parts were thus shared out according to

\footnotetext{
${ }^{26}$ The progenitor of Ife community was the first son of Oboama na Umunama, the parent-progenitors of the clan. Thus, Ife is known and regarded as the 'first son' of Ezinihitte.

${ }^{27}$ They were Umu Ada (children of the first daughter) of Umunama.
} 
tradition (Chilaka 1997: Interview). Onye Isi Eze-mmuo virtually got nothing; he shared everything out to his kits and kin (Izima; Aguwamba 1997: Interviews).

After this stage, Onye Isi Eze-mmuo called on people to present their problems. The priests then offered mass prayers for the people. They propitiated the god where and when necessary, especially for calamitous events ${ }^{28}$ or situations in the communities which they often attributed to grave infractions by the people. Then, through their priests, the people made supplications to Chileke-Oha, which often included appeals for protection and guidance, against barrenness, infertility, premature and untimely deaths, as well as for prosperity and progress, rich harvest in the next farming season, blessings for the remainder of the year, and for more (plenty of) children - a consistent request of virtually all persons, families and entire communities in attendance (Izima; Chilaka; Aguwamba 1997: Interviews). The officiating priests later thanked Chileke-Oha for numerous blessings, including for population increase, bumper harvest (if they had one), and general protection from various harms (Ibid).

After the prayer sessions $O j i$ took its rightful place in the festivities. Oji was presented and blessed with certain incantations to and invocations before Chileke-Oha (Chilaka 1997: Interview). Ngumah observed that at the center of this ritual feast was the $I$ chi Oji (collection of kola) traditional rite. According to him, “... [T] he kola nuts were passed from one community to the other. The passing of $O j i \underline{i}$ served as a roll call of the communities, to know which ones were absent and also as a communion of identity" (Ngumah 1984). Ichi Oji was performed among the communities according to seniority and in the spirit of fraternity, conviviality and friendship; everyone present at the worship-ritual eventually took and ate a piece of $O j i$.

At the end of the observances of the $O j i$ traditional rites, people with 'special problems' were given some of the blessed $O j i$ to chew in acceptance of the blessings of Chileke-Oha. Oku- $u f a$ (a big terracotta pot used for preparing Ufa) was provided in which the Onye Isi Eze mmuo dissolved some Nzu, Odo (yellowish clay-earth powdery substance), Mmanyị-ukwu and Mmiri uju (harvested 'sacred' rain water), thus making a semi-soluble mixture known as Ụfara (or Ụfa). This soluble substance (Ụfara) was used for blessing the people (Chilaka 1997: Interview). As was further noted, this semisoluble mixture was known as Ufara (or Ufa) and was used for blessing the people (Chilaka 1997: Interview). As was further noted:

\footnotetext{
${ }^{28}$ Such calamities could be pestilence and/or strange deaths, wars, massive invasion of pests, or even lean harvests.
} 
Barren women at the ceremony were blessed with a firm promise of bearing children before the end of the year. Each of them was given $O j i$ i to chew and $U f a$ was used in blessing them. They were signed with Uffa on their forehead and on the navel. All present also got signed with Uffa. They also took some home to their respective villages and households for blessing those who could not attend the annual worship-ritual for whatever reasons (Izima 1997: Interview).

Each Eze-mmuo was then called upon to advance to the shrine with his people. This was done community by community according to their order of affinity, after which collective communal prayers were offered. Those that had some special problems stayed back for extra days of prayers. It was the belief that those with problems, after attending this festival, has such issues resolved. Uko music was repeated and danced to soon after the communal prayers. This signaled the end of the annual worship. Those who had some special problems stayed back for extra days of prayers. It was the belief that those with problems, after attending this worship, had such issues resolved. Onye Isi Eze-mmụo bade everyone farewell, charging them to go home "without looking back”, for Chileke- Ọha's blessings to be effective (Chilaka 1997: Interview).

From all indications, the annual worship was not just important for and appealing to the people, but was equally relished by them. A popular saying in Ezinihitte clan: Emewe Emume Chileke-Oha, ya adịa abali adikwala (when the feast of Chileke-Oha is going on, it is wished that night never came) aptly captures this feeling: Indeed, this underlines the thorough satisfaction most people derived from Emume Chileke-Oha.

\section{Colonial legacies: of disruption and revival}

Colonialism was a very disruptive force in Africa. Similarly, cultural systems have eroded as a result of the over-bearing influence of Christianity. Very much like many other aspects of traditional African religious and social life, the importance and reputation of Emume Chileke-Ohawas greatly eroded during the years of British colonialism. In contradistinction, however, the period equally provided a rare opportunity for resilience, renewal, revival and renaissance among the newly emergent educated African elite of the post-First World War and nationalist eras. Accordingly, 
colonialism had two diametrically opposite effects on Emume Chileke-Oha-it destroyed the indigenous religion, conversely, however, it made possible the emergence of new resilient elite who revived the defunct communal feast. These two dynamics would be examined.

\section{Disruption of the religious practices}

Emume Chileke-Oha Orieukwu continued among Ezinihitte people until the arrival and eventual penetration of the colonizing British forces into the interiors of Igboland. Part of their 'civilizing mission', was the 'conversion agenda'. Thus, they introduced and imposed a 'novel' religion in the areas where they operated. IbiniUkpabi, the famous oracle of Arochukwu, otherwise popularized by the invading colonialists as the "Long Juju", came under severe attack by the invaders, having been accused of being a decoy for 'aiding and abating' the inglorious slave trade (Afigbo 2006). It was completely destroyed during the infamous "Aro Expedition" of 1901. ${ }^{29}$ The implications of this for other powerful deities and oracles elsewhere in Igboland were grave. Soon after, other Igbo societies inhabiting such powerful deities/oracles also faced similar conquest, subjugation and obliteration of their revered deities, and by extension, religions.

Following the "Ahiara Expedition" of $1905,{ }^{30}$ the shrine of Chileke-Oha, alongside those of other 'lesser' deities in Ezinihitte, also came under severe physical attack. This was initially by the colonialists, and later by a combination of the colonialists, European missionaries and the clan's Christian converts (Izima 1997: Interview). This historical punitive activity is popularly known as Ichu Ekwensu (chasing-away the devil), while the year (1905) is referred to as Ogeachuru Ekwensu (the period when the devil was chased away). Three prominent protagonists of the 'war' against Chileke-Oha Orieukwu were the notorious colonial officers, Captains Brian Douglas and Harold Hastings ${ }^{31}$, and the missionary, Rev. David

\footnotetext{
${ }^{29}$ In November 1901, the British launched the Aro Expedition, thus triggering the Anglo-Aro War (19011902). It was a punitive warfare against the people of Arochukwu (in Igboland), who were accused of using their powerful deity, Ibini-Ukpabi, as a façade to promote the slave trade. By 28 December 1901 Arochukwu was captured, and by early 1902 the Aro Confederacy, a large slave-trading network and league, collapsed. Thus the war was over. Cf: Afigbo (1973).

${ }^{30}$ On 7 December 1905, Captain Douglas initiated the Ahiara Expedition in retaliation for the refusal of some local leaders to obey his orders and the subsequent murder of Dr. Stewart. The military action was led by Major Hugh Montague Trenchard, notoriousy known as the greatest destroyer of towns in Igboland. Cf: Ekechi (1974).

${ }^{31}$ Their notoriety essentially hailed from the fact that they championed both the Ahiara and Ezinihitte punitive expeditions in 1905. Those expeditions were popular in the affected clans where they are referred to as $O g u$ Dangalasi (Douglas' war), after its initiator, Captain Douglas. The expeditions were
} 
Cocker ${ }^{32}$. While the Captains focused on dismantling complicit structures associated with the slave trade - of which the shrine of Chileke-Oha was accused - Rev. Cocker, alongside a few other missionaries, vigorously faced the task of 'conversion of souls', particularly those of the worshippers of Chileke-Oha, to Christianity (Chilaka; AchorOdoemene 1997: Interviews; Osuagwu 2000).

With the destruction and subjugation of the shrine of Chileke-Oha, it annual worship and the religion began to decline. It was almost totally abandoned within a short period of the tragic occurrence ${ }^{33}$. A new religion, Christianity, which was introduced in its stead aggressively opposed all rituals, practices and symbols related to Emume Chileke-Oha and other "pagan" feasts. Consequently, with time just a few adherents of the traditional religion were left, and they continued to face sustained pressure and possibly, subtle intimidation, to abandon the indigenous religion ${ }^{34}$. What was clear at the time was that both the colonialists and missionaries, who many would argue - and understandably so - were one and the same, were viciously antagonistic to any support for the worship of Chileke-Oha. They considered it idolatry. With such hostile posture, the traditional worship went underground while its adherents' numbers rapidly declined, many embracing the new religion. A few years later, the Emume Chileke-Oha literarily 'died out' and was essentially forgotten (Chilaka; Izima 1997: Interviews).

\section{Revival of the festive tradition}

Despite their disruptive nature on local cultures, colonialism and Christianity had little effect on the $O j \underline{j}$ i customs and rites in Igboland. Indeed, Christian social ceremonies instead, "readily integrated the kola nut" as a significant element in their observances (Duru 2005). Such example of syncretism is a clear expression of the Igbo holding on to traditional beliefs while appropriating elements of the new religion (Olson 1996). When the shrine of Chileke-Oha was destroyed, its associated feasts were 'criminalised' while its adherents abandoned it in their numbers. Despite these, Ojị rites

essentially reprisals following the murder of Dr. Rogers Stewart by elements suspected to be from these local clans, though accusations of being a slave trade decoy were levied.

${ }^{32}$ Rev. Cocker, who resided in Ezinihitte at the time, established the Church Missionary Society (CMS) in virtually all the communities of Ezinihitte clan.

${ }^{33}$ Izima noted that there was palpable fear in the people who believed that their supreme deity, ChilekeOha, would come to their rescue and destroy the invaders; they became disillusioned and devastated on discovering that they were proved wrong and their supreme god had been disgraced and defeated and dismantled. Many of them, including this respondent, eventually converted to Christianity.

${ }^{34}$ Instructively, even the new religion's (Christian) god was given the name Chileke (Chineke), thus totally obliterating and replacing the name of the indigenous god, and in the process forcing on the locals an amnesia of Chileke-Oha and its worship. 
continued to thrive amongst Ezinihitte people; whenever there was need for clan members to congregate, Ichi Oji - a key aspect of the defunct Emume Chileke-Oha, which survived albeit in a lesser form - was basically an essential part of such occasion. Certainly, Ibara (fun show-off) associated with $I$ chị Ojị was enough to keep the practice going and close to the people's heart (Achor-Odoemene 1997: Interview).

What is today celebrated as Oji Ezinihitte cultural festival was an offshoot of Ichi Ojị activity, which evolved amongst a handful of Ezinihitte indigenes under the auspices of Onyeaghalanwanneya ${ }^{35}$ Cultural Association (OCA). Instructively, Ichi Ojị rites of OCA followed Emume Chileke-Oha pattern of Oji reverence. It started in 1937 when the association was re-named Ezinihitte Clan Union (ECU) ${ }^{36}$, and thus the practice instituted as a way of championing unity and oneness amongst its members. It was these newly-emergent elite members of ECU of that period that championed a cultural renaissance and transformation in the clan. As Ndulaka, one of its dedicated member aptly opined: "[B]y I chị Ojị activity, we welcome ourselves to the ritual of renewing the covenant oath which our fore-fathers enacted at Ihu Chileke [before the shrine of god] when they first started the festival" (Ndulaka 1997: Interview). It was this development that triggered the evolution which led to the modern-day $O j i$ festival.

In August 1953, an important meeting of ECU was held at Aba. The meeting centered on evolving another cultural event that would draw all Ezinihitte people and communities together, irrespective of religious and/or political affiliations (Ugo 1995; Ndulaka 1997: Interview). For this, the public identification of $I$ chi Ojị received wide approval. Other important decisions regarding the conduct of the public event were:

1) The festivity would be rotated in traditional order amongst Ezinihitte communities, unlike the permanent hosting at Orieukwu.

2) Instead of sacrifices at Chileke-Oha's shrine, Christian worships and prayers would be engaged.

3) The festival was to take place henceforth on the first day of each year - 1st January.

4) In place of Uko, Ekpe was adopted as the festival's official music and dance.

5) They adopted the idea of a dance competition among the communities at the festival -to add glamour and seriousness.

\footnotetext{
${ }^{35}$ The meaning of "Onyeaghalanwanneya", as noted earlier (footnote 1), goes a long way in underlining the main purpose of this cultural group, which was for increased unity and fraternity among its members.

${ }^{36}$ ECU (OCA) was a colonial-time indigenous cultural association of Ezinihitte elite who were privileged to be educated, have occupied positions of authority and welded significant political influence during the colonial era.
} 
6) The festival would be known as "Ojị Ezinihitte Cultural Festival" (Ugo 1995; Odoemene 1997; Ndulaka 1997: Interview).

Therefore, by these resolutions these notable Ezinihitte sons supported the 'transmogrification' of the ancient worship-ritual into a festival with Christian colouration (Eze J.N. Amaefula, cit. Iheanacho 2012). Similarly, they introduced the 'line of kinship and consanguinity' principle as the festival's order of rotation amongst Ezinihitte communities, which follows the Igbo tradition of $O j i$ rotating first among direct blood relations before moving to more distant ones. The adopted order was:

1. Oboama-na-Umunama, Ife, Chokoneze;

2. Ihitte, Akpodim, Amumara, Eziudo;

3. Itu, Okpofe, Ezegbogu;

4. Udo, Obizi, Onicha. ${ }^{37}$

With significant shifts in the nature, pattern and form, the stage was set for the 'rebirth', in modern times and transformed form, of the ancient Emume Chileke-Oha. Importantly, this would be without the hitherto associated "fetish sacrifices and rituals", as most Christians were wont to describe it. This revival, whatever form it took, must be understood as aspects of the innate religious consciousness and socio-cultural restoration of the people.

\section{The Ojị Ezinihitte festival in modern times}

The festival usually commenced in the mid-afternoon of 31 December every year with the formal hand-over of the treasured $O b a-O j i$ (a giant carved $O j i$ container, known as 'Old man') and sixteen Okwa-Oji (carved Oji bowls) by the Eze (king) and the council members of the immediate-past host community of their equivalents of the next host community. This traditional 'hand-over' took place at the boundary of the new host community nearest to that of the last host. The $O b a-O j i$ was covered with a piece of traditional "George" wrapper. Items, which included a male goat, bottle of "hot drink" and sixteen kola nuts ${ }^{38}$, were presented by the new host community to the immediate past host community as a demonstration of goodwill. A token amount of money was

\footnotetext{
${ }^{37}$ The rightful order has been a source of much controversy, contention and conflict. In contradistinction to this current list, Dickenson's (1932) Intelligence Report (pp. 9-10), presented the order thus: 1. Umunama; 2. Oboama; 3. Ife; 4. Amumara; 5. Umueze; 6. Umuchoko; 7. Akpoku; 8. Umudim; 9. Itu; 10. Eziudo; 11. Obizi; 12. Udo; 13. Okpofe; 14. Ihitte; 15. Eziagbogu; and 16. Onicha. There also exists the Nkwa Otile list (also by Dickinson), which apparently adds to the whole controversy.

38 Sixteen' is symbolic in acts relating to the festival. It represented the traditional Ezinihitte Communities, including the Okwuato group.
} 
also presented as "transport fare" for the $O b a-O j i$, which was covered with a piece of traditional "George" wrapper. The hand-over was done amid singing, dancing and the booming of Ntunala (indigenous canon shots) (Odoemene 1997; Dimgba 1997: Interview).

The Oba-Ojị begins its journey to the host Eze's palace after the handover. It is accompanied by traditional rulers, Ndị Nze (red-cap chiefs), officials of Ezinihitte Development Association (E.D.A.), and other members of the community present. The procession to the palace was often on foot and at a slow pace, with reverence, regality and decorum (Odoemene 1997; Dimgba 1997: Interview). At the palace, the chairmanship (leadership) of Ezinihitte Council of Traditional Rulers (ECTR) was then formally transferred to the new host $E z e^{39}$ (Dimgba 1995: Interview). Celebrations and entertainment continued in the palace till late at night. Other Ezinihitte communities were equally engulfed in celebrations that night of 31 December due to Ichu afo (traditional send-forth of the out-going year) activities ${ }^{40}$.

Early in the morning on $1^{\text {st }}$ January, a visit to the venue of the festival would reveal the host's preparedness. Booths were constructed with palm fronds ${ }^{41}$ for the respective Ezinihitte communities, special guests and dignitaries from the clan and beyond, while a special one was set up at the center for $N d i$ Eze who would oversee the event. The 'Ground Zero' of the festival is marked out indicating the strategic positioning of the different vital groups and actions - for the Ekpe music players, the judges' stand (which often has a raised platform), the direction of dance for the Ichi $Q j i \underline{i}$ competition among the communities, and the platform where the Oba-Oji would be placed. The arena was richly decorated in traditional motifs, while the booths complete with chairs -were clearly identified with name tags. Public Address System (PAS) was usually provided so people could hear, understand and follow what was being said and done.

Before midday, following sixteen Ntunala shots and the sounding of Uhie (the ancient gong), both of which traditionally announced the commencement of the festival, crowds of people from different communities of Ezinihitte and beyond would begin to arrive at the arena and taking up positions in the booths. They were enthralled by

\footnotetext{
${ }^{39}$ Any host Eze automatically holds the chairmanship position for one year.

${ }^{40}$ It is noteworthy that Ichu afo was not related in any way to the $O j i$ festival, but was an age-long end-ofyear tradition in Igbo societies through which they also welcomed the new year. Some would, however, argue that there is, indeed, a 'connection' since the festival was a harbinger of the New Year, and welcomed the people into it.

${ }^{41}$ In recent times, however, palm frond booths have been replaced with modern tarpaulin canopy-booths.
} 
various cultural displays of dances from all around Ezinihitte (Ugo 1995). At noon, Ndi Eze, finely attired in their full regalia, would dance the Nkwa Ike ('power dance') of the Ekpe performers into the arena, amidst cheers and booming of Ntunala shots. At about 12:30 PM the ceremony started in earnest. The chairman of the occasion was introduced and formal prayers were said by a Christian priest or pastor, giving blessings to the august occasion. Welcome addresses were presented by the host community, the EDA and ECTR, after which the Oba-Ojị, bearing all the Ojị, Nzu and Ose-Oji (alligator pepper) - the main items for the day's ritual (Ugo 1995) - would then make its entrance. Borne by the host Eze's cabinet members who danced regally to the designated booth, its arrival was heralded with sixteen Ntunala shots. The Oba-Ojị was placed on a platform in front of the traditional rulers (Ugo 1995).

Ichi Ojị was the climax of the Ojị Ezinihitte festival. For this event, the different communities were invited according to the present order of kin relationship (listed above) to come forward and received a single $Q k w a-O j i$ which contained $O j i, N z u$ and Ose-Ojị. The Ekpe music performers, strategically positioned for this purpose, provided the music for the invited group to dance enroute the main stand to accept the Okwa-Oji. Each community's representatives ${ }^{42}$ were often well dressed in traditional attire and were sometimes preceded by an Ekpe masquerade (Odoemene 1997). Judges for the dance competition were advantageously located so as to have a perfect view of the rhythmical movements and demonstrations of the representatives' dances. It was a moment of excitement. One observed that each invited community stepped out proudly and danced with sufficient measure of seriousness for a good show to out-class other contestants for the trophy.

The representatives stopped in front of the $O b a-O j i$ and with a token sum ${ }^{43}$ received the Okwa-Oji from the host Eze and Ndi Eze Oboama-na-Umunama, the later in their capacity as the kings of the parent communities. The representatives then danced back to their community's booth, amidst cheers of welcome and shouts of joy and rejoicing ${ }^{44}$. The items in the $O k w a-O j i$ i were subsequently shared out to everyone in the booths as a demonstration of the bond of unity and love (Ugo 1995). After the

\footnotetext{
${ }^{42}$ Normally, Ndi Nze and other prominent chiefs represented their communities for Ichi Oji activity. The number of representatives for each community is the number of the component villages which makeup the community.

${ }^{43}$ Any amount presented was acceptable.

${ }^{44}$ In some instances, especially in times of mourning - for instance, due to the loss of their Eze communities merely walked to the podium to collect their own portion. However, whatever reason that necessitated such a show devoid of fanfare would not be unknown to the public who also showed some understanding.
} 
present communities in Ezinihitte would have observed the $I c h i ̣$ Oji activity guest communities were invited to share in the $O j i$ communion. The first of such invitees was the 'Okwuato group' due to its genealogical and cultural links with Ezinihitte ${ }^{45}$. This same reason goes for Ngwa community, the second to be invited for this activity ${ }^{46}$. Other groups - clans in Mbaise, Ndị Okene (people having Ezinihitte as their maternal home), illustrious sons of Ezinihitte and some dignitaries present were also invited to partake in $I c h i ̣$ Ojị.

The formal end of the festival at the arena started with the declaration of winners by the judges; prizes were awarded, the trophy presented and refreshment (food and drink) was provided for guests present. Celebrations, however, continued in different Ezinihitte communities with visitations, merriment and exchange of gifts, especially as it was also the New Year's Day (Achor-Odoemene 1997: Interview; Maduka 1992).

\section{Competing perceptions of the Ojị Ezinihitte festival}

The Oji Ezinihitte festival means different things to different people. Opinions sought suggested that this festive ritual had its admirers, hard critics, as well as a variation of perceptions in-between. There existed many hardcore lovers of tradition who would not compromise the festival, no matter the reason. Representative voice of this group noted thus:

This is our culture, so why shy away from it? It is our pride as Igbo that $O j i$ is celebrated. God himself blessed us with it. Other places around the world also have what they celebrate as 'tradition', and they do so without shame. Many of our 'born again' brothers who refuse to partake in the festival go to the Whiteman's land and practice their 'traditions'. But here, they condemn what God blessed us with. That is unacceptable. I will continue to celebrate Ojị Ezinihitte festival. Nothing can stop me (Osuagwu 2017: Interview).

Besides these 'lovers of tradition', one needs to acknowledge that there seem to be deliberate denigration of the essence and significance of the festival by many. Some have castigated it as 'unfit' because of its "pagan origins". According to one such view:

\footnotetext{
${ }^{45}$ Members of the "Okwuato Group" have never hosted the $O j i$ festival since its revival in 1953.

${ }^{46}$ Instructively, the Okwuato and Ngwa groups were invited for Ichi $O j i$ even before other clans in Mbaise.
} 
The Oji festival is real idolatry and paganism - pure and simple. You need not go far to verify this. Just look at its origins. What does it point to? Idolatry and paganism! And that is what I have been warning the people about; the Bible says 'My people die of ignorance'. ...If the root or origin [of the celebrations] is faulty, then forget it; it's ungodly. As Christians, it's against our belief and should be abandoned. It is evil and we must put an end to it (Madu 2017: Interview).

A few have assumed and argued, albeit ignorantly, that it is merely an "invented tradition" based on fables and myths, which were adopted without critical examination (Eberendu 2017: Interview). Similarly, erroneous suggestions of the festival "being forced on the people" were sometimes made. Contrary to these thoughts, it should be noted that at no time was the $O j i$ f festival 'forced' or made binding on people in whatever form; there were no sanctions whatsoever for not participating in it. Undeniably, some of these views were not surprising; the knowledge of the origins and importance of the festival has largely faded, particularly under the over-bearing influence of Christianity and the people's passionate receptivity to change and Western lifestyles. Nonetheless, this fact has never diminished the festival. On the contrary, it has continued to gain grandeur and prominence both within and outside of Ezinihitte ${ }^{47}$ (Achor-Odoemene 1997: Interview). Instructively, these competing opinions cut across the religious, the 'aristocracy', as well as the 'ordinary people'.

Finally, contrary to views in some quarters that since the revival of the festival in 1953, it has continued to be hosted 'unbroken' till date, evidence suggests otherwise. The Nigeria-Biafra (1967-1970) obstructed the festival and the ravages of that war were quite evident in the clan. The 'second round' of the festival started in 1977 with Ife hosting (Odoemene 1997).

\section{Conclusion}

The Oji Ezinihitte cultural festival is an offshoot and transformed form of the annual ancient worship-ritual, Emume Chileke-Oha Orieukwu, which collapsed in the early twentieth century due to antagonistic external intrusions. Its revival came through

\footnotetext{
${ }^{47}$ The fact is that $O j i$ Ezinihitte festival is presently commemorated in many countries around the world (in the UK, USA, Ireland, Canada, Cameroon, etc) where Ezinihitte people are found in some reasonable numbers.
} 
the efforts of the Ezinihitte clan's indigenous elite who felt the urge to maintain a link with their culture and worldview. This underlines how, while old orders were destroyed by foreign interference, the people were able to use its revival to reinvent their identification modes. In modern times, the cultural festival has become enthralling and estimable as the people share $O j i$ and make meaning out of it. While it is true that $Q_{j i}$ is highly revered throughout Igboland, nowhere else is it meaningfully celebrated in its full symbolism - even throughout Igboland - as in Ezinihitte. Indeed, it was at this $O_{j i}$ festival of Ezinihitte people, more than any other place or event, that $O j i$ is demonstrated as the greatest symbol of life, love, reconciliation, conviviality, affinity, reunion, peace and oneness. These peculiar qualities were tokenly displayed in this festival where $Q j i \underline{i}$ was the main item of ritual.

Ojị Ezinihitte annual ritual had particular socio-cultural significances. It underlined the fact of a common ancestry and heritage of Ezinihitte clan, which needed to be continuously highlighted and celebrated (Odoemene 1997). Furthermore, it was a festival that was hinged on brotherhood and communal bonds, qualities which put in ritual form the name Onyeaghalanwanneya - the bedrock of Ezinihitte solidarity. Being more than just an avenue for the reaffirmation of communal bonds, it also reinforced the history of the founding of Ezinihitte, thus, the festival rituals were vital in understanding the coming into existence of the clan (Iheanacho 2012). Very importantly too, the festival preserved a core element of a pan-Igbo cultural heritage by conserving knowledge of its past (religious origins and settlement history), as well as its erosion and revival - all of which would otherwise have been destroyed and lost for certain political and over-zealous religious reasons. Additionally, the festival offered a platform for identifying socio-economic and political challenges faced by the people, especially as it signifies a bond of primordial unity among the constituents. Thus, as Ihediwa et al. (2014) have posited, Ezinihitte people often took advantage of the festival to organize themselves politically, particularly for community development purposes, often times only achievable through self-help efforts.

Conflicts of Interest: The author declares no conflict of interest 


\section{References}

\section{Interviews}

Achor-Odoemene, Sir. Cornelius Eluwanya. Otulu-Amumara Ezinihitte; Interviewed: 26 July 1997.

Aguwamba, Mazi Philip Okechukwu. Eziagbogu-Ezinihitte; Interviewed: 28 September 1997.

Anyanwu, Chief Cletus Anele. Owerri; Interviewed: 28 May 1997.

Chilaka, Chief Alexander I. Onunekwuru Oha I of Umunama. Umunama-Ezinihitte; Interviewed: 20 and 25 September 1997.

Dimgba, H.R.H. Eze L.N. Ofọ Ire I of Itu. Itu Ezinihitte; Interviewed: 22 September, 1997.

Eberendu, Dr. Christian. Obokwu-Obizi Ezinihitte; Interviewed: 03 January 2017.

Izima, Ichie Fredrick (Former Native doctor and devotee to the shrine of Chileke-Oha). Umuome-Umunama Ezinihitte; Interviewed: 25 September 1997.

Madu, Pastor Peter (Elijah). Umuchoko-Chokoneze Ezinihitte; Interviewed: 05 January 2017.

Ndulaka, Chief Timothy. Umuche-Eziagbogu Ezinihitte; Interviewed: 21 September 1997.

Odoemene, Mr. Godfrey Ndubuisi. Otulu-Amumara, Ezinihitte; Interviewed: 12 April 1997.

Onuoha, Barrister G.N. Umuome Umunama, Ezinihitte; Interviewed: 20 September 1997.

Osuagwu, Mr. Augustus. Umuoma-Okpofe Ezinihitte; Interviewed: 02 January 2017.

\section{Articles and books}

Abaka E. 2000. "Kola Nut." In Kiple K.F. and Ornelas K.C. (eds.). The Cambridge World History of Food. Cambridge: Cambridge University Press.

Achebe C. 1958. Things Fall Apart. New York: Alfred A. Knopf. 
Achebe C. 2012. There was a Country: A Personal History of Biafra. London: Penguin Press.

Acholonu C.O. 2008. "Ogam Philosophical Language and the Lost Nation of Tilmun", in: Reflections on Indigenous Philosophical Thought. Abuja: UNESCO.

Afigbo A.E. 1973. "The Calabar Mission and th Aro Expedition of 1901-1902", Journal of Religion in Africa, 5(2): 94-106.

Afigbo A.E. 1981. "The Age of Innocence," AhiajokuLecture. Owerri: Government Press.

Afigbo A.E. 2006. The Abolition of the Slave Trade in Southeastern Nigeria, 18851950. Rochester, NY: University of Rochester Press.

Anidobe C.J. and Uzoalor U.J. 2010. "Kola Nut: Kolanut as an Embodiment for Completeness of the Igbo Culture", The Nigerian Academic Forum, 19(2) (November): $1-5$.

Apakama L.M. 2012. "Igbo Kolanut: It's Socio-cultural Significance for Peace", in Anedo A.A.O. and Udemmadu T.N. (eds.) The Ideal Man: Festschrift in Honour of Professor Obed Muojekwu Anizoba (Ozonwa). Awka: Apple Books Publishers.

Basden G.T. 1966. Niger Ibos. London: Frankcass.

Chidume A.V. 1998. "The Rite of Kolanut: A Case study of Nimo, Njikoka Local Government Area of Anambra State." Unpublished Diploma in Religion Project, University of Nigeria, Nsukka (UNN).

Chidume C.G., Osisioma U.S. and Echem, S.O. 2015. "The Symbolism of Kolanut in Igbo Cosmology: A Re-Examination", International Journal of Research in Humanities and Social Studies, 2(8): 51-56.

Chuwkunyere H. 2004. "Oji Ezinihitte Festival in Imo State", Nigerian Heritage Journal,13.

Classycut 2012. "Kolanut and Tradition", Hubpages.com/hub/kolanut (accessed: 23 December 2019).

Dickinson E.N.C. 1931. Intelligence Report on Ezinihitte Clan, Colonial Administration Report, Eastern Provinces, 9343A, no. 39 (Great Britain).

Duru M.C. 2005. "When Signifying Goodwill is No Longer Enough: the Kola Nut and Gender among Igbos in Nigeria and Belgium," Food and Food ways: Explorations in the History and Culture of Human Nourishment, 13(3), 201-219.

Egbufoama C. 2008. "The Immanency of the Kola Nut: Reconnaissance into its Inherency in Igbo Belief System", Codewit CSN: 14719. 
Ejiogu E.C. 2015. "Age-old Democratic Social Authority Patterns: The Bases of Igbo Identity and Politics", Igbo Studies Review, 3(20): 1-33.

Ekechi F.K. 1974. "Igbo Resistance to British Imperialism: The Episode of Dr. Stewart and the Ahiara Expedition, 1905-1916”, Journal of African Studies, 1(2): 145-157.

Iheanacho D.A. 2012. Mbaise: Who We Are As a People. Owerri: Edu-Edy Publications.

Ihediwa N.C., Nwashindu, V. and Onah, C.M. 2014. "Kola Nut (Oji) Cultural Festival in Ezinihitte Mbaise, Imo State," Journal of Tourism and Heritage Studies, 3(1): 38-47.

Isichei E. 1976. A History of the Igbo People. London: Macmillan Press Ltd.

Isichei E. 1997. A History of African Societies. New York: Cambridge University Press.

Jell-Bahlsen S. 2014. Mammy Water in Igbo Culture: Ogbuide of Oguta Lake. Enugu: Ezu Books.

Khoko E. 1984. "Igbo Kola Bowls West of the Cross River," Nigeria Magazine, No. 148, Department of Culture, F.M.S.D.Y.C., Lagos.

Maduka R.O.E. 1992. “Oji Ezinihitte Festival.” In Ife 1992, Ife Publicity Committee, Ife-Ezinihitte.

Ngumah F.E. 1984. "Ezinihitte Clan and the Oji festival", In Okpofe 1984 - Brochure for the Oji Ezinihitte Festival by Okpofe Publicity Committee, Okpofe Ezinihitte.

Nnaemeka O. 2013. "Igbo Humanism: Mapping Horizontal Reasoning and Theology of Nearness," Keynote Address, Igbo Studies Association (ISA) Annual Conference, Enugu (June 28).

Nnamdi-Eruchalu G.I. 2012. "A Study of the Language of Kola Nut in Traditional Igbo Setting”, Academic Discourse: An International Journal, 2 (1): 169-180.

Nweke A.C. 2015. "The Mystico-Religio-Linguistic Dimensions of Kolanut Ritual", IKENGA: International Journal of Institute of African Studies UNN, 17(1): 125-133.

Nwosu E.B. 2003. Kolanut: Igbo Sacramental Communion. Owerri: Pajob Strides.

Nzeako J.U.T. 1979. Omenala Ndi Igbo. Lagos: Longman.

Nzekwu O. 1961. "Kola Nut", Nigerian Magazine, No. 68, Department of Culture, F.M.S.D.Y.C., Lagos.

Odoemene A. 1997. "Ojị Ezinihitte Cultural Festival: Legend and Legacy," Unpublished B.A. Long Essay, Department of History, Imo State University, Owerri, Nigeria. 
Offiaeli R. 2015. "When the Kola Nut (Cola Acuminata) Meets the Electric Slide: Constructing Transnationalisms", PhD Dissertation 724, University of Connecticut.

Okoloye A.O. and Enemuo J. 2019. "Symbolic Importance of Kola Nut in Igbo Worldview", Nnamdi Azikiwe Journal of Philosophy, 11(4): 80-85.

Olson J.S. 1996. The Peoples of Africa: An Ethnographic Dictionary (London: Greenwood Press).

Opata D.U. 1998. Essays on Igbo World-view. Nsukka: AP Express Publishers.

Oriji J.N. 1981. "The Ngwa-Igbo Clan of Southeastern Nigeria: An Oral History Overview", Oral History Review, 9(1): 65-84.

Osuagwu P. 2000. "The Orji Ezinihitte Cultural Festival: A Symbol of Tradition, Unity and Development," a published pamphlet on the festival. Conclave Publishers, Owerri.

Talbot P.A. 1926. The Peoples of Southern Nigeria. London: Oxford University Press.

Uchendu V.C. 1965. The Igbo of South-eastern Nigeria. New York: Holt Reinhart and Winston.

Uchenna T. 2010. "Osu caste in Igboland", Vanguard Online Edition (09 October); http://www.vanguardngr.com/2010/10/osu -caste-in-igboland/ (accessed: 14 May 2016).

Ugo A.N. 1995. “Akpodim'95” - Brochure for the Oji Ezinihitte Festival by Akpodim Publicity Committee, Akpodim Ezinihitte.

Ugo. A.N. 1993. “Oji Ezinihitte Cultural Festival”, Unpublished Manuscript.

Umeogu B.C., Onebunne J.I., Ojiakor C.I. and Etodike C.E. 2019. "Kolanut and Symbolismic Universe: Towards the Creation and Constitution of Igbo Science and Arts", Canadian Social Science, 15(4): 1- 6.

Yalae P. 2008. Neo-Africanism: The New Ideology for a New Africa. Bloomington, IN: Trafford Publishing.

\footnotetext{
Akachi Odoemene is Professor of African History and Head, Department of History and International Studies (2016-date), Federal University Otuoke, Nigeria. He is the current National Secretary of the Historical Society of Nigeria (HSN) and a Research Fellow of the Collaborative Working Group of the African Peace building Network (APN), Social Science Research Council (SSRC), New York, USA (20182020). He was a Global Leaders Postdoctoral Research Fellow at the Global Economic Governance Programme (GEG), University College Oxford (2013-2014) and a Neihaus Postdoctoral Research Fellow at the Woodrow Wilson School (WWS), Princeton University, USA, (2014-2015). His research focuses on Social and Cultural History, Peace and Conflict Research, African Historiography, Ethnic and Gender Studies, and Development Studies.
} 
To cite this article:

Odoemene A. 2020. Historical dynamics of Oji Ezinihitte cultural festival in Igboland, Nigeria

International Journal of Modern Anthropology. 2 (13): 67 - 98

DOI: http://dx.doi.org/10.4314/ijma.v2i13.2

\section{(๑) $\Theta \Theta$}

This article, as all articles published in this journal, is under The Creative Commons Attribution: Attribution-NonCommercial-NoDerivatives 4.0 International (CC BY-NC-ND 4.0).

https://creativecommons.org/licenses/by-nc-nd/4.0/ 